Plan to create agency for US weapons labs
under strong criticism

[WASHINGTON] Leading congressmen from both parties in the US House of

Representatives are fighting a plan to reform the nuclear weapons laboratories by placing them under a semi-autonomous agency within the Department of Energy.

The plan is championed by Senator Pete Domenici (Republican, New Mexico). It has wide support in the Senate and the partial backing of energy secretary Bill Richardson. But opponents say it is insufficiently radical to address security concerns in the wake of allegations of Chinese espionage at the Los Alamos laboratory in New Mexico, and would in fact protect the managers responsible for these concerns.

The House subcommittee that controls the energy department's budget proposed last week that it should be cut severely next year - and that an additional \$1 billion for the weapons laboratories should be held in reserve until the management structure of the labs is reformed. Ron Packard (Republican, California), chair of the subcommittee, is believed to want to use the measure to negotiate more radical reforms than those proposed by Domenici.

Two days earlier, John Dingell

(Democrat, Michigan), the senior minority member of the House Commerce

Committee, had led a separate bipartisan attack on Domenici's plan at hearings of two House subcommittees. Dingell described the proposal for a semi-autonomous agency as "using gasoline to extinguish a fire".

Dingell and other Democrats compared Domenici's proposal to the Atomic Energy Commission, which operated the weapons laboratories until the mid-1970s. Although remembered fondly by some physicists, the commission is regarded by Dingell as an example of closed government. "It was one of the most arrogant and incompetent government agencies I ever saw," he said.

Republicans on the panel, meanwhile, attacked the management abilities of the energy department. They said they would prepare legislation to restructure it.

Packard's subcommittee proposed large across-the-board cuts in the energy department budget, including cuts of \$525 million in President Bill Clinton's request for the nuclear weapons programme, \$250 million in energy supply programmes and \$350 million in environmental clean-up.

The House is now preparing its own legislation to reform the department. But observers say that Domenici, as a senior member of several committees that oversee the labs, is in a strong position to defend them from radical changes. Colin Macilwain

\title{
\$3m deal launches major hunt for drug leads in Brazil
}

[SÃO PAULO] The pharmaceutical multinational Glaxo Wellcome and a small Brazilian biotechnology company signed a \$3.2-million contract last week to screen up to 30,000 compounds of plant, fungus and bacterial origin from several regions in the country. The initiative is described as the world's largest natural product sampling and screening programme.

As part of the three-year deal, the companies have agreed that one-quarter of any royalties arising from successfully exploited patents will be used to support communitybased conservation, health and education projects. This reflects recent heated debates over how compensation should be paid by companies that turn indigenous knowledge' into commercial products.

According to Jorge Raimondo, Glaxo's regional director for Latin America, a further 25 per cent of the royalties will go to the university group responsible for isolating and identifying the product in question. Glaxo Wellcome will pay for all research and development costs in Brazil. The research will focus on compounds found in the Amazonian and Atlantic rainforests, and Glaxo Wellcome will have an option to license any product arising from it.

Raimondo says the agreement reflects the company's view that, despite the increasing use of combinatorial chemistry to screen large quantities of artificially synthesized molecules, there is still much to be learned from traditional remedies. "One of our main interests, for example, is the way that some of these compounds control pain."

Officials from Glaxo and the Brazilian company, Extracta, point out that the agree- ment has been made possible by — and conforms with - new legislation on intellectual property introduced in Brazil after a fierce political debate on the protection of genetic material (see Nature 392, 538; 1998). They say that it also conforms with the United Nations Convention on Biological Diversity, which specifies that the interests of local communities must be taken into account.

"With both Brazil's new patent law and the country's rich biodiversity, the moment is now appropriate to invest in Brazilian science," says Padraic Ward, Glaxo's manager for business development in Latin America.

Antonio Paes de Carvalho, Extracta's director-general and a biophysics professor at the Federal University of Rio de Janeiro, says Brazilian researchers often complain that multinationals do not invest in local research. "This contract opens the way for similar companies to join other university centres," he says. "It is the beginning of a change in attitude."

Paes de Carvalho says the Glaxo-Extracta contract is different from the \$1-million screening deal signed a few years ago by Merck and Costa Rica's INBIO. In contrast to that agreement, scientists in Brazil will work on the identification of molecules and the study of their biological properties, rather than just processing plant extracts for analysis abroad.

According to Raimondo, Glaxo is particularly interested in molecules with potential antibiotic, anti-inflammatory and possibly antifungicide properties. Paes de Carvalho says that one of his goals is to create a databank of all the samples and molecules screened. RicardoBonalumeNeto \& David Dickson

\section{Outspoken science minister ousted in reshuffle}

[SÃO PAULO] Brazilian president

Fernando Henrique Cardoso last week replaced the science minister, Luiz Carlos Bresser Pereira, in a ministerial reshuffle. The job went to diplomat Ronald Sardenberg, a personal friend of the president, and previously secretary for special projects and secretary for strategic affairs.

Bresser Pereira, an economist, had been science minister for the first six months of Cardoso's second term, having replaced José Israel Vargas, who held the post for a record six years. Bresser Pereira was known among scientists for a certain impetuosity and for making controversial statements. He aroused considerable animosity among researchers in northeast Brazil with comments about the quality of the science done there.

Whether or not the minister's style played a part in his replacement, the reshuffle was intended primarily to redistribute favours among the political parties that support Cardoso. For a while the science ministry was expected to go to a member of one of these parties, but Cardoso eventually decided to appoint someone whom the scientific community could be comfortable with.

Cardoso has said that he considers the ministry's role to be "strategic". "We'll see what happens when the budget for 2000 appears," comments the new president of the Brazilian Society for the Advancement of Science, biochemist Glaci Zancan, from the Federal University of Paraná.

R.B. N. 